\title{
Whole-cell immunocytochemical detection of nitrogenase in cyanobacteria: improved protocol for highly fluorescent cells
}

\author{
Yukiko Taniuchi ${ }^{1,3}$, Akio Murakami ${ }^{2}$, Kaori Ohki ${ }^{1, *}$ \\ ${ }^{1}$ Department of Marine Bioscience, Faculty of Biotechnology, Fukui Prefectural University, 1-1, Gakuencho, \\ Obama, Fukui 917-0003, Japan \\ ${ }^{2}$ Kobe University Research Center for Inland Seas, 2746, Iwaya, Awaji, Hyogo 656-2401, Japan \\ ${ }^{3}$ Present address: Department of Marine Biotechnology and Resources, National Sun Yat-sen University, \\ Kaoshiung 80424, Taiwan
}

\begin{abstract}
An improved immunocytochemical method was developed to detect nitrogenase in single cells of cyanobacteria using a unicellular diazotrophic strain (Gloeothece sp. 68DGA) and a nondiazotrophic strain (Synechocystis sp. PCC6714) as model organisms. Polyclonal antibodies raised against the Fe-protein and the MoFe-protein ( $\alpha$-subunit) of nitrogenase were used as probes. The antigenicity of nitrogenase was maintained for at least 6 mo when the cells were preserved in chilled methanol $\left(-30^{\circ} \mathrm{C}\right)$ after paraformaldehyde fixation $(3 \%)$. The cells were permeabilized for antibody penetration and non-specific binding was prevented by incubation in phosphate-buffered saline containing dimethyl sulfoxide $(10 \%)$ and normal rabbit serum $(15 \%)$. Antibody binding was visualized by a horseradish peroxidase-conjugated secondary antibody and the chromogenic substrate 3-3'diaminobenzidine tetrachloride because of the difficulty in discriminating between fluorescence from additive fluorochrome and natural autofluorescence from cyanobacteria. Almost all cells (>97\%) were immunostained when they were grown diazotrophically and expressed nitrogenase (acetylene reduction) activity. Non-specific staining of both the diazotrophic strains grown with combined nitrogen and the non-diazotrophic strain was negligible. Our protocol was able to detect nitrogenase in unicellular and filamentous non-heterocystous strains without modification.
\end{abstract}

KEY WORDS: Diazotrophic unicellular cyanobacteria $\cdot$ Marine cyanobacteria $\cdot$ Immunocytochemical detection $\cdot$ Nitrogenase $\cdot$ Unicellular cyanobacteria

\section{INTRODUCTION}

Recent biogeochemical studies have suggested that the contribution of $\mathrm{N}_{2}$ fixation to the nitrogen budget of the ocean is more important than previously believed (for reviews, see Zehr \& Ward 2002, Galloway et al. 2004, Mahaffey et al. 2005). As a member of the prokaryotes, many cyanobacteria fix $\mathrm{N}_{2}$. The most important source of nitrogen in the marine environment is filamentous non-heterocystous cyanobacteria of the genus Trichodesmium (for reviews, see Mulholland \& Capone 2000, Capone et al. 2005). Diazotrophic unicellular cyanobacteria have previously been isolated from marine environments (Mitsui et al. 1986, Waterbury et al. 1988, Reddy et al. 1993, Falcón et al. 2004a, Ohki et al. 2008). However, their contribution to the nitrogen budget of the global ocean has not been recognized until recently (for a review, see Zehr \& Ward 2002).

Unicellular cyanobacteria of 3 to $10 \mu \mathrm{m}$ diameter were present at a cell density of 10 and 150 cells ml- in 0.2 to $10 \mu \mathrm{m}$ particle fractions. As this particle fraction showed nitrogenase activity, it was suggested that these unicellular cyanobacteria were responsible for 
$\mathrm{N}_{2}$-fixation (Zehr et al. 2001). Transcripts of the cyanobacterial nifH gene, which encodes the Fe-protein of nitrogenase, were detected in the filtered fraction of 0.2 to $10 \mu \mathrm{m}$ particles obtained from a depth of 25 to $150 \mathrm{~m}$ in the oligotrophic waters of the North Pacific Ocean (Zehr et al. 2001, Church et al. 2005). The level of nifH mRNA derived from unicellular cyanobacteria was comparable with that of Trichodesmium spp. (Church et al. 2005). Similar observations were reported for oligotrophic waters of the southern tropical and equatorial Pacific Oceans (Neveux et al.1999) and the Baltic Sea (Wasmund et al. 2001). Furthermore, unicellular cyanobacteria with a genetic potency for diazotrophy were detected in waters of the Arabian Sea (Mazard et al. 2004) and the Atlantic and Pacific Oceans (Falcón et al. 2004b) using 16S rDNA based PCR analysis. In addition, diazotrophic unicellular cyanobacteria cells $(<10 \mu \mathrm{m}$ in diameter) were successfully detected in the coral lagoon waters of New Caledonia by the so-called tyramide signal amplification system, whereby fluorochrome-tyramide in situ hybridization (TSA ${ }^{\mathrm{TM}}$-FISH) was performed using a DNA fragment of 16S rDNA (NITOR821; Mazard et al. 2004) as a probe (Biegala \& Raimbault 2008). The cell density of unicellular cyanobacteria with a genetic potency for diazotrophy in this study was estimated to be between 0.6 and $10^{2}$ cells $\mathrm{ml}^{-1}$, which is comparable to or even 1 order of magnitude higher than that of Trichodesmium spp. ( 1 to 5 cells ml ${ }^{-1}$; cf. Zehr et al. 2000, 2001). There is no doubt that diazotrophic cyanobacteria of unicellular forms contribute to the nitrogen budget of the ocean. $\mathrm{N}_{2}$-fixation is primarily regulated at the level of transcription of the nitrogenase gene (for a review, see Sherman et al. 1998). Therefore, detection of nitrogenase mRNA or protein in individual cells is necessary to estimate the number of $\mathrm{N}_{2}$-fixing cells. However, the exact cell numbers that fix $\mathrm{N}_{2}$ in the ocean have not yet been determined, because it is impossible to identify $\mathrm{N}_{2}$-fixing cells from their morphology.

Detection of transcripts of the nifK gene, which encodes the $\beta$-subunit of the MoFe-protein of nitrogenase, in single cells has only been reported in the heterocystous cyanobacterium Anabaena spp. using a radio-labeled probe (Madan \& Nierzwicki-Bauer 1993). There are few reports on the immunocytochemical detection of cytoplasmic proteins in single cells of cyanobacteria: in 2 cases, the protein was located on the cell surface (Campbell et al. 1983, Scanlan et al. 1997). No positive results could be obtained when the immunocytochemical protocol for detection of cytoplasmic proteins in eukaryotic phytoplankton was applied to cyanobacterium Synechococcus sp. CCMP 1334 (Lin \& Carpenter 1996). The thick cell wall (glycocalyx; cf. Fig. 2 in Gantt 1994) of cyanobacteria may prevent the penetration of antibodies into the cells. Immunocytochemical detection of nitrogenase (Feprotein) in individual cells of Trichodesmium spp. has been reported (Lin et al. 1998, Berman-Frank et al. 2001, El-Shehawy et al. 2003). However, the results are difficult to evaluate because the bright autofluorescence emitted from fixed Trichodesmium spp. cells exceeded the fluorescence from the fluorochrome probe (Ohki 2008).

The aforementioned studies indicate that at least 2 factors are critical for whole-cell immunocytochemical detection of cytoplasmic proteins in cyanobacteria: permeablization of the cell wall for antibody penetration and avoiding the masking effect of the autofluorescence that is emitted from cyanobacterial cells. In the present study, we systematically examined different pre-treatment conditions for the detection of nitrogenase in cyanobacteria and visualized immunoreactivity using an enzyme-conjugated secondary antibody and a chromogenic substrate.

\section{MATERIALS AND METHODS}

Strains and culture conditions. The cyanobacterial strains used in this study are listed in Table 1. All diazotrophic strains were cultured in the medium with or without combined nitrogen $\left(10^{-3} \mathrm{M} \mathrm{NaNO}_{3}\right.$ or $10^{-4} \mathrm{M}$ urea). The culture media were Aquil (Morel et al. 1979) after partial modification (cf. Ohki et al. 1986, for Gloeothece spp. 68DGA and 11DGA, Gloeocapsa spp. 20B and 38CU6, Trichodesmium sp. NIBB1067 and Lyngbya sp. 10B) and BG11 (cf. Rippka et al. 1979, for Synechocystis sp. PCC6714 and Anabaena cylindrica IAM-M1). Fluorescent light (FL20SS·D/18, Toshiba) at a light intensity of $50 \mu \mathrm{mol}$ photons $\mathrm{m}^{-2} \mathrm{~s}^{-1}$ was used. The diazotrophic, unicellular and filamentous nonheterocystous strains were grown under 12:12 h light:dark cycles. A. cylindrica IAM-M1 (heterocystous strain) and Synechocystis sp. PCC6714 (non-diazotrophic unicellular strain) were grown under continuous illumination. All cultures, except for Trichodesmium sp. NIBB1067, were aerated to avoid sinking or clump formation; Trichodesmium sp. NIBB1067 cultures were routinely mixed by hand 2 to 3 times a day. The culture temperature was $25^{\circ} \mathrm{C}$. The experiments were carried out with the cells from at least 3 separate cultures.

Cells were grown in culture until they reached the middle exponential growth phase. To obtain cells that maximally synthesize nitrogenase, unicellular strains and Lyngbya sp. 10B were harvested in the middle of the dark phase of the light:dark cycle (Ohki et al. 1999, Taniuchi \& Ohki 2007), and Trichodesmium sp. NIBB1067 in the middle of the light phase of the 
Table 1. Strains, culture conditions, nitrogenase activity and the immunocytochemical detection of nitrogenase. Nitrogenase activities are measured as an acetylene reduction; activities are expressed per cell, per mol chlorophyll $a$ and per heterocyst (including proheterocyst) bases for unicellular, non-heterocystous and heterocystous strains, respectively, mean $\pm \mathrm{SD}$; nd: not detected

\begin{tabular}{|c|c|c|c|}
\hline Strain & $\begin{array}{l}\text { Nitrogen } \\
\text { source }\end{array}$ & $\begin{array}{l}\text { Nitrogenase activity } \\
\quad\left(\mathrm{mol} \mathrm{C}_{2} \mathrm{H}_{2} \mathrm{~h}^{-1}\right)\end{array}$ & $\begin{array}{l}\text { Stained } \\
\text { cells }(\%)\end{array}$ \\
\hline \multicolumn{4}{|l|}{ Unicellular } \\
\hline \multicolumn{4}{|l|}{ Diazotrophic } \\
\hline Gloeothece sp. 68DGA ${ }^{\mathrm{a}}$ & $\begin{array}{c}\mathrm{NaNO}_{3} \\
\mathrm{~N}_{2}\end{array}$ & $\begin{array}{c}\text { nd } \\
32.6 \times 10^{-16}\end{array}$ & $\begin{array}{l}2.8 \pm 0.9^{\mathrm{d}} \\
97.4 \pm 3.1^{\mathrm{d}} \\
93.7 \pm 2.9^{\mathrm{e}} \\
\operatorname{nd}^{\mathrm{d}, \mathrm{f}}\end{array}$ \\
\hline Gloeothece sp. 11DGA ${ }^{\mathrm{a}}$ & $\begin{array}{l}\mathrm{NaNO}_{3} \\
\mathrm{~N}_{2}\end{array}$ & $\begin{array}{c}\text { nd } \\
45.3 \times 10^{-16}\end{array}$ & $\begin{array}{l}3.3 \pm 0.9^{\mathrm{d}} \\
97.3 \pm 0.8^{\mathrm{d}}\end{array}$ \\
\hline Gloeocapsa sp. 201 ${ }^{\mathrm{a}}$ & $\begin{array}{c}\mathrm{NaNO}_{3} \\
\mathrm{~N}_{2}\end{array}$ & $\begin{array}{c}\text { nd } \\
26.6 \times 10^{-16}\end{array}$ & $\begin{array}{c}4.7 \pm 0.4^{\mathrm{d}} \\
97.9 \pm 4.7^{\mathrm{d}}\end{array}$ \\
\hline Gloeocapsa sp. 38CU6 ${ }^{\mathrm{a}}$ & $\begin{array}{c}\mathrm{NaNO}_{3} \\
\mathrm{~N}_{2}\end{array}$ & $\begin{array}{c}\text { nd } \\
31.0 \times 10^{-16}\end{array}$ & $\begin{array}{l}2.8 \pm 0.1^{\mathrm{d}} \\
100 \pm 0.0^{\mathrm{d}}\end{array}$ \\
\hline $\begin{array}{l}\text { Non-diazotrophic } \\
\text { Synechocystis sp. PCC6714 }\end{array}$ & $\mathrm{NaNO}_{3}$ & nd & $0 \pm 0.2^{\mathrm{d}}$ \\
\hline \multicolumn{4}{|l|}{ Filamentous } \\
\hline $\begin{array}{l}\text { Non-heterocystous-diazotrophic } \\
\text { Lyngbya sp. } 10 \mathrm{~B}^{\mathrm{b}}\end{array}$ & $\begin{array}{l}\mathrm{NaNO}_{3} \\
\mathrm{~N}_{2}\end{array}$ & $\begin{array}{l}\text { nd } \\
3.3\end{array}$ & $\begin{array}{c}5 \pm 0.3^{\mathrm{d}} \\
93.7 \pm 5.5^{\mathrm{d}}\end{array}$ \\
\hline Trichodesmium sp. NIBB1067 & $\begin{array}{l}\text { Urea } \\
\mathrm{N}_{2}\end{array}$ & $\begin{array}{c}\text { nd } \\
38.2\end{array}$ & $\begin{array}{c}\text { nd } \\
96.1 \pm 1.57^{\mathrm{d}}\end{array}$ \\
\hline \multicolumn{4}{|l|}{ Heterocytous } \\
\hline Anabaena cylindrica IAM-M1 & $\mathrm{N}_{2}$ & $108.8 \times 10^{-16}$ & $\begin{array}{c}76.9 \pm 10.5^{\mathrm{d}, \mathrm{g}} \\
\mathrm{nd}^{\mathrm{d}, \mathrm{h}}\end{array}$ \\
\hline \multicolumn{4}{|c|}{ 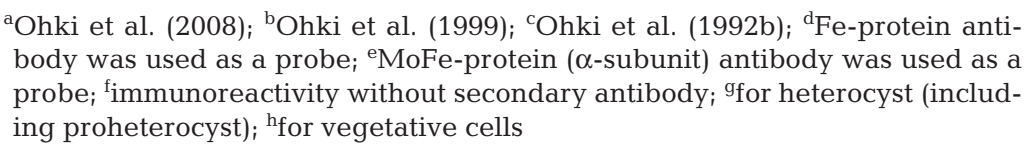 } \\
\hline
\end{tabular}

Immunocytochemical experiments. Fixation and preservation of cells: The diazotrophic strains grown in medium without combined nitrogen were used as a positive control. The diazotrophic strains grown with combined nitrogen and the non-diazotrophic strain Synechocystis sp. PCC 6714 were used as negative controls. The strain Gloeothece sp. 68DGA was used to optimize the conditions for each process. The results were evaluated by whether (1) the cells remained intact, (2) the antigenicity of nitrogenase was preserved in positive control cells, (3) immunostaining was uniform, (4) results were reproducible and (5) non-specific staining was negligible.

The cell pellets were re-suspended in PBS or PBS containing fixative, paraformaldehyde (PFA, Nakarai, Kyoto, 1, 2 or $3 \%$ wt/vol) or glutaraldehyde (GA, Nakarai, 1, 2 or $3 \%$ vol/vol), and kept at $4^{\circ} \mathrm{C}$ for 1,4 or $6 \mathrm{~h}$. The cells were then collected, re-suspended in chilled methanol or ethanol $\left(-30^{\circ} \mathrm{C}\right)$ and stored at $-30^{\circ} \mathrm{C}$ for up to 6 mo.

Cells resuspended in methanol or ethanol were washed once with PBS. In some instances, we attempted to reduce the autofluorescence emitted from fixed cells with heat treatment $\left(65^{\circ} \mathrm{C}\right.$ for $1 \mathrm{~h}$; Scanlan et al. 1997 ) or protease treatment (Pro-

light:dark cycle (Ohki et al. 1992a). A sample of the harvested cells was used to determine nitrogenase (acetylene reduction) activity, and the rest of the cells were collected by centrifugation $\left(6000 \times g, 4^{\circ} \mathrm{C}, 10 \mathrm{~min}\right)$, with the exception of Trichodesmium sp. NIBB1067, which were strained through a $5 \mu$ m nylon mesh. Cells were washed once with phosphate-buffered saline (PBS, $0.9 \times 10^{-3} \mathrm{M}$ Na-K phosphate, $\mathrm{pH} 7.4$ containing $1.37 \times 10^{-3} \mathrm{M} \mathrm{NaCl}$ and $3 \times 10^{-3} \mathrm{M} \mathrm{KCl}$ ) prior to immunocytochemical detection.

Nitrogenase activity. Nitrogenase activity was measured using the acetylene reduction method as described previously (Ohki \& Fujita 1988). Activity was expressed per cell for unicellular strains, per mol chlorophyll a base for filamentous non-heterocystous strains or per heterocyst (including proheterocyst) for the heterocystous strain. Chlorophyll a concentrations were measured spectrophotometrically in methanol extracts using the absorption coefficient of Mackinney (1941). teinase $\mathrm{K}$ [Sigma], $1 \mathrm{mg} \mathrm{ml}^{-1}$ in distilled $\mathrm{H}_{2} \mathrm{O}$ at $4{ }^{\circ} \mathrm{C}$ for 15 min; Schönhuber et al. 1999) at this point.

Permeabilization and blocking: The cells were made permeable for antibody penetration (termed 'permeabilization' hereafter) and blocked to prevent non-specific binding reactions with the antibody (termed 'blocking' hereafter). The reagents tested for permeabilization were dimethylsulfoxide (DMSO, 0.1, 1 , 5 or $10 \% \mathrm{vol} / \mathrm{vol}$, Wako), sodium dodecylsulfate (SDS, $1 \% \mathrm{wt} / \mathrm{vol}$, Wako), lysozyme $(0.01,0.1$ or $0.5 \%$ wt/vol, Sigma), $t$-octylphenoxypolyethoxyethanol (Triton $\mathrm{X}-100,0.1,1$ or $5 \% \mathrm{vol} / \mathrm{vol}$, Bio-Rad) or polyoxyethylenesorbitan monolaurate (Tween-20, 0.5 or $1 \%$ vol/vol, Sigma). The reagents tested for blocking were bovine serum albumin (BSA, 1, 5 or $10 \%$ wt/vol, Sigma), normal rabbit serum (NRS, 1, 5, 10, 15 or $20 \%$ vol/vol, Equitech-Bio) or skimmed milk $(1,5$ or $10 \%$ wt/vol, Difco). These reagents were dissolved in PBS or PBS containing $\mathrm{NaOH}\left(10^{-1} \mathrm{M}\right)$. Incubation was carried out at $4^{\circ} \mathrm{C}$ for $15 \mathrm{~min}, 1,2,3,4,5$, or $12 \mathrm{~h}$. 
Immunoreactivity: After permeabilization and blocking, the cells were washed with PBS and incubated with a primary antibody at $4^{\circ} \mathrm{C}$. Immunoreactions were carried out with polyclonal antibodies generated against the recombinant nitrogenase proteins (the Fe-protein (nifH) and the $\alpha$-subunit of the MoFeprotein(nifD)) from Trichodesmium sp. NIBB1067 (Ohki 2008). Antibody dilutions were 1/100, 1/500, 1/1000, $1 / 2000$ or $1 / 3000$ for the Fe-protein antibody, and $1 / 1000,1 / 2000$ or $1 / 3000$ for the MoFe-protein $(\alpha-$ subunit) antibody. Incubation times were 15, $30 \mathrm{~min}, 1$, 2 or $4 \mathrm{~h}$ for the Fe-protein antibody, and 15 or $30 \mathrm{~min}$ for the MoFe-protein ( $\alpha$-subunit) antibody.

Visualization of immunoreactivity: After incubation with the primary antibody, the cells were washed 3 times with PBS containing $0.2 \%$ (vol/vol) Triton X-100. They were then incubated in the secondary antibody at room temperature for 15, $30 \mathrm{~min}$ or $1 \mathrm{~h}$.

Dilutions of the fluorochrome-conjugated goat antirabbit IgG (Alexa Fluor ${ }^{\circledR}$ 350, Molecular Probe) were made in PBS containing $0.2 \%$ of Triton X-100 (1/200, $1 / 500,1 / 1000,1 / 2000$ or $1 / 3000$ ). If cells were incubated in the horseradish peroxidase (HRP)-conjugated goat anti-rabbit IgG (dilutions: 1/500, 1/1000, 1/2000 or 1/3000, Bio-Rad), cells were washed 3 times with PBS containing $0.2 \%$ Triton X-100 and immersed in 3-3'diaminobenzidine tetrachloride (DAB) solution (tris (hydroxymethyl) aminomethane (Tris)-HCl buffer $\left(10^{-2}\right.$ $\mathrm{M}, \mathrm{pH} 7.5)$ containing $\mathrm{DAB}(0.1 \% \mathrm{wt} / \mathrm{vol})$ and $\mathrm{H}_{2} \mathrm{O}_{2}$ $(0.3 \% \mathrm{vol} / \mathrm{vol}))$ at room temperature for $1 \mathrm{~h}$. When an alkaline phosphatase (AP)-conjugated goat anti-rabbit IgG (dilution: 1/2000; Promega) was employed, the cells were washed 3 times in PBS containing $0.2 \%$ Triton X-100 and immersed in Tris buffer $\left(10^{-1} \mathrm{M}, \mathrm{pH} 9.5\right)$ containing $\mathrm{NaCl}\left(10^{-1} \mathrm{M}\right), \mathrm{MgCl}_{2}\left(5 \times 10^{-3} \mathrm{M}\right)$, 4-nitroblue tetrazolium chloride (NBT, $0.33 \% \mathrm{wt} / \mathrm{vol}$ ) and 5-bromo-4-chloro-3-indolyl-phosphate (BCIP, 0.165\% $\mathrm{wt} / \mathrm{vol}$ ) at room temperature for $1 \mathrm{~h}$.

Detection and quantification of immunoreactivity. Following incubation in the Alexa Fluor ${ }^{\circledR}$ 350-conjugated secondary antibody, cells were observed under an epifluorescence microscope (BX51, Olympus) equipped with a filter set (DM400/BP330-385/BA420/ DM400; excitation $340 \mathrm{~nm}$ with a full width at a half maximum of $40 \mathrm{~nm}$ [termed 'UV-excitation' hereafter], emission longer than $430 \mathrm{~nm}$ ). The fluorescence spectrum of a single cell was measured with a microscope fluorometer (BX50; Olympus, equipped with a PMA-11 multi-channel photodiode array detector; Hamamatsu Photonics) with the same filter set as that used for epifluorescence microscopy. When HRP- or AP-conjugated secondary antibodies and their associated chromogenic substrates were used, observations were carried out under a light microscope (BX51, Olympus). The number of stained cells was determined with trip- licate counts of 200 cells or 100 trichomes (ca. 10000 cells for Trichodesmium sp.). The values were expressed as mean $\pm \mathrm{SD}$ (Tables $1 \& 2$ ).

\section{RESULTS AND DISCUSSION}

\section{Probes used to visualize immunoreactivity}

All diazotrophic strains grown in medium without combined nitrogen showed acetylene reduction activity, but no activity was detected in the cells grown with combined nitrogen (Table 1). We first examined several kinds of probe to visualize the immunoreactivity. A secondary antibody tagged with a fluorochrome was the first choice because immunoreactivity can be semiquantified by fluorescence intensity (cf. Sambrook \& Russell 2001). A green-fluorescent probe that is widely used for studies of plant cells cannot be used with cyanobacteria because the fluorescence is quenched by phycoerythrin. A blue-fluorescent probe is preferentially used for cyanobacteria (cf. Lin et al. 1998), because the autofluorescence emitted from photosynthetic pigments is low in the blue wavelength region. Alexa Fluor ${ }^{\circledR} 350$ emits blue fluorescence by UV-excitation, suggesting that it would be a suitable candidate. However, we found that cells treated with the primary antibody alone emitted bright violet to blue fluorescence by UV-excitation, and we could not distinguish between cells incubated with primary antibody alone or with primary and Alexa Fluor ${ }^{\circledR}$ 350-conjugated secondary antibody under an epifluorescence microscope, even when the concentration of the secondary antibody was increased (dilution: 1/200, see Fig. A1A,B in Appendix 1, available online as AME Supplementary Material at: www.int-res.com/ articles/suppl/a051p237_app.pdf). The same problem was noted when a fluorochrome-tagged probe was applied to unicellular cyanobacteria collected from the Atlantic and Pacific Oceans (Falcón et al. 2004b) or to cultured strain Trichodesmium sp. NIBB1067(Ohki 2008, see also Appendix 1: Fig. A1C, D). The spectrum of autofluorescence emitted from individual fixed cells of Gloeothece sp. 68DGA overlapped with that of Alexa Fluor ${ }^{\circledR} 350$, as determined by a microscope fluorometer (Fig. 1A, curve a vs. Fig. 1B, dotted line). The fluorescence intensity in the blue wavelength region was enhanced after secondary antibody treatment (Fig. 1A, curve a vs. curve b). However, the enhancement was too low to discriminate the true immunoreaction signal unless a difference spectrum was plotted (Fig. 1B, solid line). Previously, heat treatment was successfully used to reduce autofluorescence when a homolog of PstS protein was detected in marine Synechococcus spp. (Scanlan et al. 1997). However, we found that heat treatment decreased the antigenicity of nitrogenase (data not shown). 
Table 2. Immunocytochemical detection of nitrogenase (Fe-protein) in 3 samples containing a known mixture of unicellular cyanobacteria from different strains

\begin{tabular}{|lccc|}
\hline Strain & $\begin{array}{c}\text { Cell } \\
\text { number ratio }\end{array}$ & $\begin{array}{c}\text { Expected no. of } \\
\text { diazotrophic cells }\end{array}$ & Stained cells (\%) \\
\hline Gloeothece sp. 68DGA:Synechocystis sp. PCC6714 & $1: 1$ & 50 & $48.5 \pm 7.7$ \\
Gloeothece sp. 68DGA:Synechocystis sp. PCC6714 & $6: 5$ & 54.5 & $50.7 \pm 10.9$ \\
Gloeothece sp. 68DGA:Gloeocapsa sp. 20B:Synechocystis sp. PCC6714 & $3: 2: 2$ & 71.4 & $77.1 \pm 10.9$ \\
\hline
\end{tabular}

The PstS homolog protein is reported to be membraneembedded (Carr \& Mann 1994, Scanlan et al. 1993, 1997), but nitrogenase is a soluble cytoplasmic protein, so these proteins may have different tolerances to heating. Furthermore, we pretreated with a protease to reduce autofluorescence (Schönhuber et al. 1999), but this caused cellular collapse.
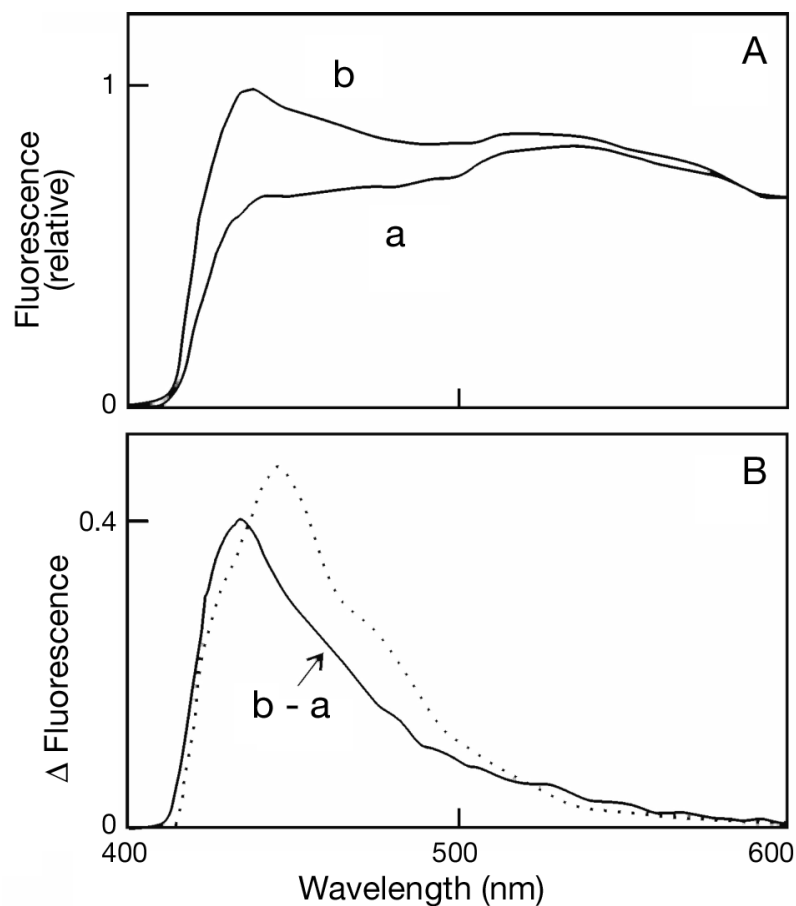

Fig. 1. (A) Fluorescence emission spectra of a single cell of Gloeothece sp. 68DGA before (curve a) and after (curve b) incubation with an Alexa Fluor ${ }^{\circledR}$ 350-conjugated secondary antibody. Fixed cells were incubated with the Fe-protein antibody after permeabilization and blocking. Fluorescence intensities were normalized at a maximum of chlorophyll a fluorescence $(685 \mathrm{~nm})$. (B) Fluorescence difference spectrum of a single cell of Gloeothece sp. 68DGA, i.e. after minus before (curve b - curve a in A) incubation with an Alexa Fluor ${ }^{\circledR} 350$ conjugated secondary antibody (solid line). The fluorescence emission spectrum of Alexa Fluor ${ }^{\circledR} 350$ (dotted line) is also presented. Fluorescence spectra were measured with a microscope fluorometer and an excitation light was $340 \mathrm{~nm}$ with a full width at a half maximum of $40 \mathrm{~nm}$. Color images obtained by epifluorescence microscopy are available online as Supplementary Material (Appendix 1: Fig. A1) at: www.int-res.com/articles/suppl/a051p237_app.pdf
To avoid the masking effect caused by autofluorescence, the immunoreaction signal must be amplified using a probe conjugated to an enzyme (cf. Sambrook \& Russell 2001). To this end, we used an HRP-conjugated secondary antibody and immunoreactivity was visualized with the chromogenic substrate DAB. Immunoreactivity was observed as a dark-brown deposition of oxidized DAB. Using Gloeothece sp. 68DGA as a test organism, each step of the immunocytochemical reaction was evaluated.

Use of the chromogen DAB is not ideal because it is a possible carcinogen (cf. Sambrook \& Russell 2001); therefore, we also tried an AP-conjugated secondary antibody and the chromogenic substrates NBT and BCIP. Immunoreactivity was visualized as a dark-blue deposition of diformazan under a light microscope (Appendix 1: Fig. A2), though the color was not as prominent as that of oxidized DAB. In addition, $\mathrm{TSA}^{\mathrm{TM}}$-FISH could be used to overcome autofluorescence (I. Biegala pers. comm.).

\section{Fixation and preservation}

The cells collapsed (Appendix 1: Fig. A3A) and/or aggregated (Appendix 1: Fig. A3B), when they were preserved in chilled methanol or ethanol $\left(-30^{\circ} \mathrm{C}\right)$ without fixation. There was good preservation of morphology and protein antigenicity by fixation with PFA (3\% in PBS, at $4^{\circ} \mathrm{C}$ for 4 to $6 \mathrm{~h}$, Appendix 1: Fig. A3A,C). Similar conditions were successfully used in immunocytochemical detection of cytoplasmic proteins in marine eukaryotic phytoplankton cells $\left(4 \%\right.$, at $4^{\circ} \mathrm{C}$ for 6 h, Lin \& Carpenter 1996). Reproducible immunoreactivity could not be obtained when the PFA concentration was lowered $(<2 \%)$ or when the incubation time was shortened $(<2 \mathrm{~h})$. Fixation with GA (1 to $3 \%$, at $4^{\circ} \mathrm{C}$ for 1 to $6 \mathrm{~h}$ ) resulted in poor preservation of protein antigenicity. Antigenicity of the PFA-fixed cells was maintained for at least 6 mo when cells were preserved in methanol at $-30^{\circ} \mathrm{C}$. Uneven immunostaining due to cell aggregation occurred when cells were preserved in ethanol at $-30^{\circ} \mathrm{C}$.

Permeabilization was necessary for clearly visible and uniform immunostaining. Of the permeabilization reagents tested, DMSO appeared to be the most effec- 
tive. Reproducible and uniform immunostaining was achieved when the cells were incubated in $10 \%$ DMSO (in PBS at $4^{\circ} \mathrm{C}$ for 4 h, Fig. 2A,C, Appendix 1: Fig. A4A,C). Higher concentrations of DMSO $(0.5 \%)$ and longer incubation times (15 $\mathrm{min})$ were required when compared with eukaryotic phytoplankton cells (Lin \& Carpenter 1996), which may be due to the thick cell wall (glycocalyx) of cyanobacteria. Lysozyme (0.01 to $0.5 \%$ ) and Tween-20 (0.5 to $1 \%$ ) were less effective than DMSO and permeability was not increased by extending the incubation times to $12 \mathrm{~h}$. Treatment with SDS ( $1 \%$ in PBS containing $\left.10^{-1} \mathrm{M} \mathrm{NaOH}\right)$ or Triton X$100(0.1$ to $5 \%)$ resulted in uneven staining, mainly due to cell aggregation (Appendix 1: Fig. A3C). A high degree of non-specific background staining was observed when $1 \%$ Triton X-100 was applied (Appendix 1: Fig. A3D).

\section{Blocking}

Blocking of non-specific binding sites to reduce nonspecific staining is a step that has often been omitted in previous studies of cyanobacteria and marine phytoplankton (Lin \& Carpenter 1996, Lin et al. 1998, Berman-Frank et al. 2001, El-Shehawy et al. 2003). However, for all of the strains tested, we found that negative control cells were non-specifically stained when the blocking step was omitted (data not shown). The most reproducible blocking was obtained when the cells were incubated with NRS $\left(10 \%\right.$ in PBS at $4^{\circ} \mathrm{C}$ for $4 \mathrm{~h}$ ): non-specific staining was completely suppressed by incubation in $15 \%$ NRS without loss of specific immunoreactivity (Fig. 2A vs. B, C vs. D, Appendix 1: Fig. A4A vs. B, C vs. D); however, concentrations of NRS $>20 \%$ reduced specific immunostaining. BSA ( 1 to $10 \%$ ) and skimmed milk (1 to $10 \%$ ) were less effective: non-specific staining to some extent was always observed in negative control cells grown without combined nitrogen. Furthermore, the specific immunostaining in positive control cells that have nitrogenase activity was reduced when the concentration of BSA or skimmed milk was increased $(>10 \%)$. The same results were obtained when cells were treated with permeabilization reagents and blocking reagents simultaneously or during separate incubations; therefore, permeabilization and blocking were carried out at the same time by immersing the cells in PBS containing DMSO (10\%) and NRS (15\%) at $4^{\circ} \mathrm{C}$ for $4 \mathrm{~h}$.

\section{Immunoreactivity and staining}

Following permeabilization and blocking, the cells were incubated with the primary antibody at $4^{\circ} \mathrm{C}$ for

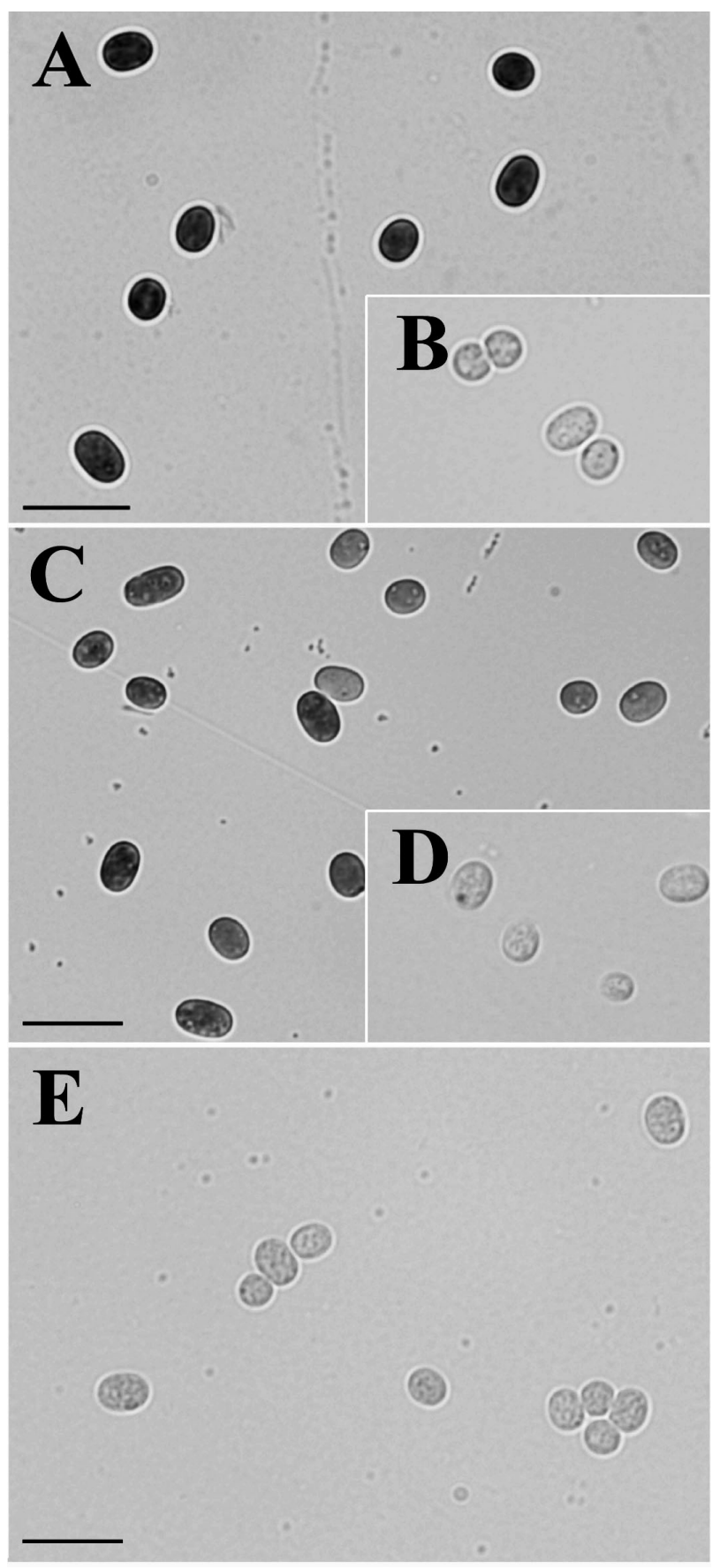

Fig. 2. Immunocytochemical detection of nitrogenase proteins in Gloeothece sp. 68DGA grown $(\mathrm{B}, \mathrm{D})$ with or $(\mathrm{A}, \mathrm{C}, \mathrm{E})$ without combined nitrogen. Fixed cells were incubated with $(A, B)$ the Fe-protein antibody or $(C, D)$ the MoFe-protein ( $\alpha$-subunit) antibody after permeabilization (in 10\% dimethylsulfoxide for $4 \mathrm{~h}$ ) and blocking (in 10\% normal rabbit serum for $4 \mathrm{~h}$ ). Immunoreactivity was visualized with a horseradish peroxidase (HRP)-conjugated secondary antibody and 3-3'-diaminobenzidine tetrachloride. (E) Same as in (A), but incubation with the HRP-conjugated secondary antibody was omitted. Scale bars $=10 \mu \mathrm{m}$. Color images are available online as AME Supplementary Material (Appendix 1: Fig. A4) at: www.int-res.com/articles/suppl/a051p237_app.pdf 
15 min. A distinct immunoreactivity was obtained at a dilution of $1 / 2000$ for both Fe- and MoFe-protein $(\alpha-$ subunit) antibodies of nitrogenase (Fig. 2C, Appendix 1: Fig. A4C). The immunostaining was not enhanced by increasing the primary antibody concentration (dilutions between 1/1000 and 1/100) or by extending the incubation time (30 min to $4 \mathrm{~h}$ ). After incubation with the primary antibody, the cells were washed 3 times with PBS containing Triton X-100 (0.2\%), and then incubated with the HRP-conjugated secondary antibody. Clear immunostaining was obtained with the secondary antibody at a dilution of 1/2000 and an incubation time of $15 \mathrm{~min}$ at room temperature. The immunostaining was not enhanced by increasing the secondary antibody concentration (dilutions between $1 / 1000$ and $1 / 500$ ) or by extending the incubation time (30 min to $1 \mathrm{~h}$ ). After the cells were washed 3 times with PBS containing Triton X-100 (0.2\%), the immunoreactivity was visualized by incubation with DAB solution. The deposition of oxidized DAB was optimal after approximately $1 \mathrm{~h}$ at room temperature. The dark-brown deposition of oxidized DAB was clearly and distinctly observed in the cells of Gloeothece sp. 68DGA grown in the medium free of combined nitrogen (for the Fe-protein antibody, Fig. 2A, Appendix 1: Fig. A4A; for the MoFe-protein [ $\alpha$-subunit] antibody, Fig. 2C, Appendix 1: Fig. A4C). More than $95 \%$ of the cells that expressed nitrogenase activity were immunostained (Table 1). The deposition of oxidized DAB was not present in the negative control cells grown with combined nitrogen (Fig. 2D, Appendix 1: Fig. A4D). Less than $3 \%$ of cells were weakly stained in the negative control cells (Table 1). Non-specific oxidation of DAB by endogenous peroxidases was a concern, but no deposition of oxidized DAB was detected in the cells not treated with HRPconjugated secondary antibody (Fig. 2E, Appendix 1: Fig. A4E, Table 1).The immunoreactivity visualized with oxidized DAB was preserved for at least $1 \mathrm{wk}$ without any loss of the specific signal or formation of non-specific DAB-oxidation products in the negative control cells, when the cells were washed 3 times in PBS and stored in PBS containing Triton X-100 (0.2\%) at $4{ }^{\circ} \mathrm{C}$. The protocol for immunocytochemical detection developed in this study is summarized in Fig. 3. Cells prepared in the same way, but immunostained with Alexa Fluor $350^{\circledR}$ probe, NBT/BCIP or DAB are also presented in Fig. A5 of Appendix 1.

\section{Application to various types of cyanobacteria}

Our newly developed protocol was applied for the detection of nitrogenase (Fe-protein) in different types of cyanobacteria. The results clearly showed that our protocol could detect nitrogenase in diazotrophic unicellular strains of different genera, Gloeothece sp. and Gloeocapsa spp. (Fig. 4A,C,E, Appendix 1: Fig. A6A,C,E). More than $97 \%$ of the cells that expressed nitrogenase activity were immunostained (Table 1). The deposition of oxidized DAB was not

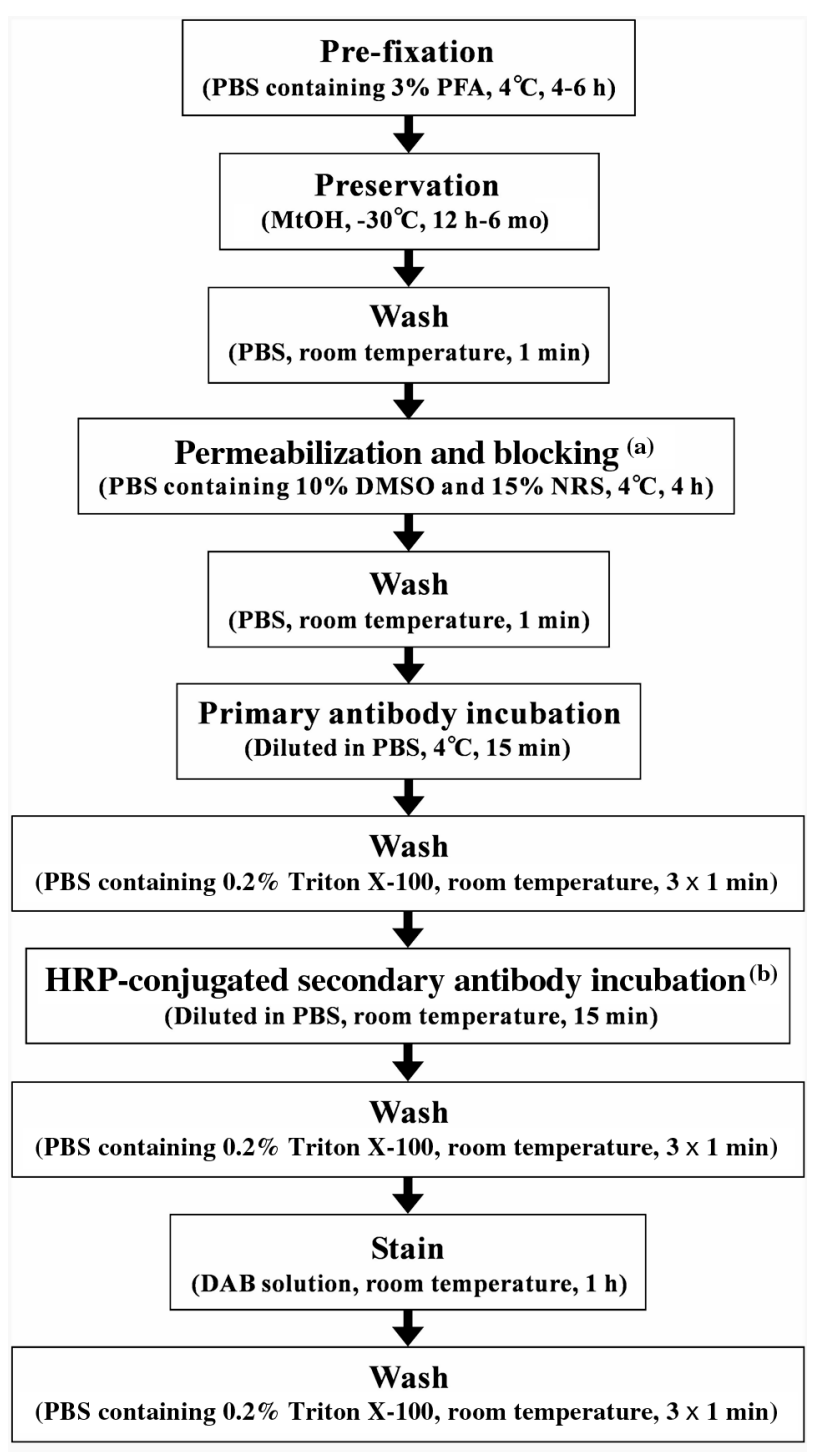

Fig. 3. Flow chart of the present protocol. Dilutions of the Feprotein antibody, the MoFe-protein ( $\alpha$-subunit) antibody and the secondary antibody were $1 / 2000$. (a) For the heterocystous strain, phosphate-buffered saline (PBS) containing SDS (1\%), $\mathrm{NaOH}\left(10^{-1} \mathrm{M}\right)$ and $15 \%$ normal rabbit serum (NRS) was used. ${ }^{(b)}$ To visualize immunoreactivity, an alkaline phosphatase-conjugated secondary antibody and 4-nitroblue tetrazolium chloride/5-bromo-4-chloro-3-indolyl phosphate was used instead of a horseradish peroxidase (HRP)-conjugated secondary antibody and 3-3'-diaminobenzidine tetrachloride (DAB) (see Appendix 1: Fig. A2, available online as AME Supplementary Material at: www.int-res.com/articles/ suppl/a051p237_app.pdf). PFA: paraform-aldehyde; MtOH: methanol; DMSO: dimethyl sulfoxide 
observed in diazotrophic strains grown with combined nitrogen ( $<5 \%$, Fig. 4B,D,F, Appendix 1: Fig. A6B,D,F, Table 1). Staining of the non-diazotrophic unicellular strain Synechocystis sp. PCC6714 was negligible (Fig. 4G, Appendix 1: Fig. A6G, Table 1).

Nitrogenase could also be detected in the filamentous non-heterocystous cyanobacteria, form-genus Lyngbya sp. 10B and Trichodesmium sp. NIBB1067, without modification of the protocol (Appendix 1: Fig. A7A,C). Almost all cells (>94\%) were immunostained in non-heterocystous strains that were cultured without combined nitrogen (Table 1). Again, nonspecific staining was $<5 \%$ (Fig. A7B,D, Table 1). Ubiquitous distribution of nitrogenase (Fe-protein) was observed in Trichodesmium spp. collected from the western Caribbean Sea and coastal Atlantic Ocean by immunoelectron microscopy (Paerl et al. 1989). However, other groups (Fredriksson \& Bergman 1997, Lin et al. 1998, Berman-Frank et al. 2001, El-Shehawy et al. 2003) reported that nitrogenase was limited to about 9 to $25 \%$ of the total cells of Trichodesmium spp. Fredriksson \& Bergman (1997) designated such nitrogenase-containing cells 'diazocytes'. A fluorochrome (Alexa Fluor $350^{\circledR}$ )-conjugated secondary antibody was used to visualize immunoreactivity in their experiments; however, it was later shown that the bright autofluorescence emitted from Trichodesmium spp. cells masked the fluorescence emitted from Alexa Fluor $350^{\circledR}$ (Ohki 2008). Nitrogenase (both Fe- and MoFeprotein) was detected in almost all (>95\% of total cells) Trichodesmium sp. NIBB1067 cells grown under nitrogen-limited conditions, when the immunoreactivity was visualized by a chromogenic probe (HRP/ $\mathrm{DAB} / \mathrm{H}_{2} \mathrm{O}_{2}$, Ohki 2008). Ohki (2008) concluded that Trichodesmium sp. NIBB1067 did not develop heterocyst equivalent diazocyte cells. The results obtained in

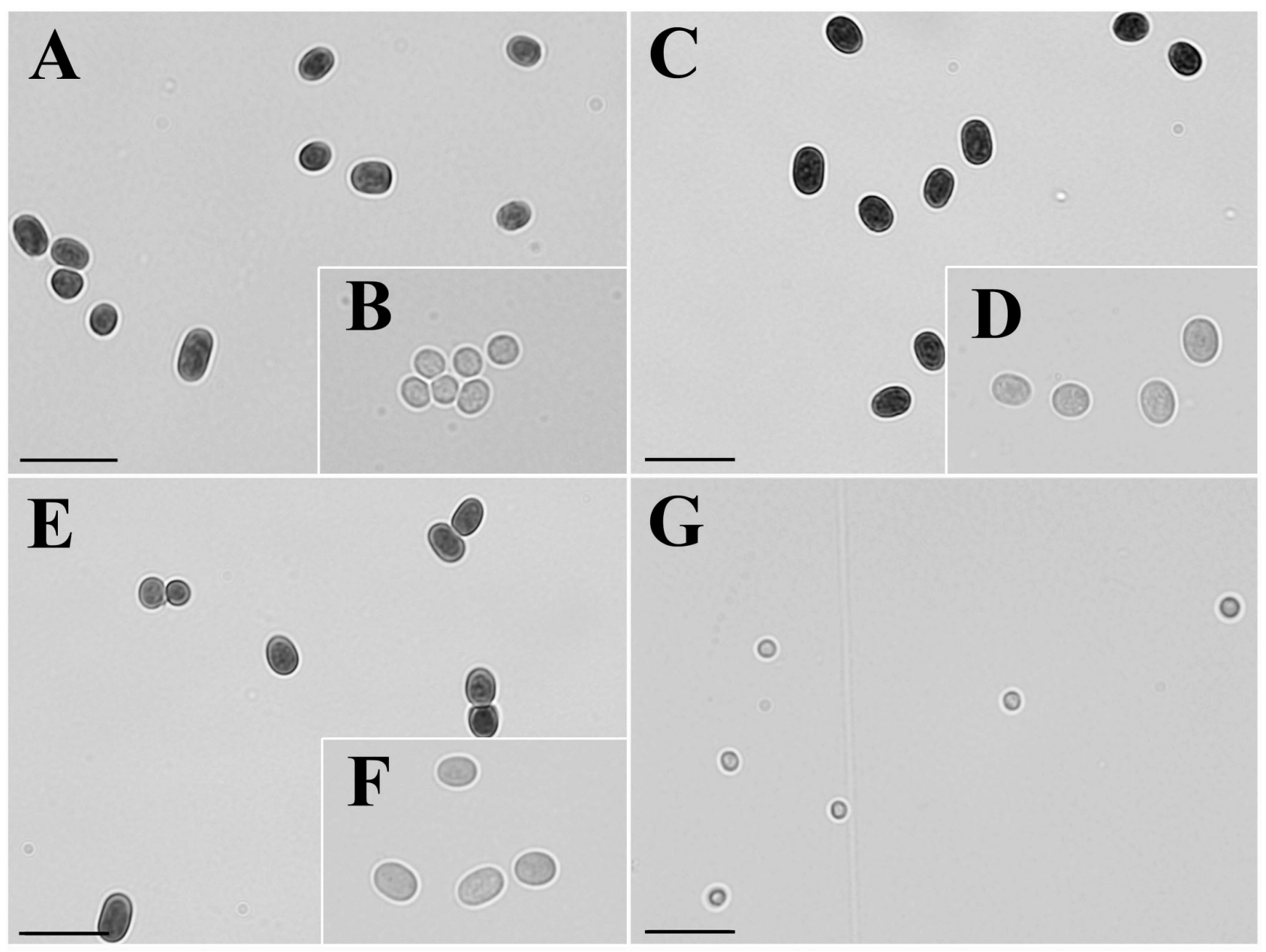

Fig. 4. Immunocytochemical detection of nitrogenase (Fe-protein) in the diazotrophic strains (A,B) Gloeothece sp. 11DGA, (C,D) Gloeocapsa sp. 20B, (E,F) Gloeocapsa sp. 38CU6 and (G) a non-diazotrophic strain Synechocystis sp. PCC6714. Cells were grown $(\mathrm{B}, \mathrm{D}, \mathrm{F}, \mathrm{G})$ with or $(\mathrm{A}, \mathrm{C}, \mathrm{E})$ without combined nitrogen. Scale bars $=10 \mu \mathrm{m}$. Color images are available online as AME Supplementary Material (Appendix 1: Fig. A6) at: www.int-res.com/articles/suppl/a051p237_app.pdf 
the present study confirm the previous findings of Paerl et al. (1989) and Ohki (2008). As $\mathrm{N}_{2}$-fixation of Trichodesmium spp. occurs preferentially during the daytime or the light phase of light:dark cycles (Saino \& Hattori 1978, Ohki et al. 1992a), there must exist a mechanism(s) to protect nitrogenase from the oxygen $\left(\mathrm{O}_{2}\right)$ produced by photosynthesis. Heterogeneity and temporal changes of Photosystem II (PSII) status were observed in individual cells within the same trichome of Trichodesmium spp. (Berman-Frank et al. 2001, Küpper et al. 2004). All Trichodesmium spp. cells had PSII, but some of the cells, designated 'type I bright cells', had PSII linked to pseudo-cyclic electron transport, rather than PSI. The inter-conversion between a bright cell and a cell with normal PSII occurred, and the abundance of type I bright cells was high during the time of active $\mathrm{N}_{2}$-fixation. Küpper et al. (2004) proposed that the type I bright cells were able to maintain a low $\mathrm{pO}_{2}$ because the electrons produced by PSII were used to reduce $\mathrm{O}_{2}$ via pseudo-cyclic electron transport (Mehler reaction). Light-dependent $\mathrm{O}_{2}$-consumption was recently detected in Trichodesmium sp. ISM101 (Milligan et al. 2007). In Trichodesmium spp., nitrogenase is synthesized in all cells, and may be converted between its active and inactive form or turned over, depending on the PSII status of individual cells.

In our study, permeabilization by DMSO was not effective with heterocysts, probably due to their thick wall. Treatment with SDS $\left(0.1 \%\right.$ in PBS containing $10^{-1}$ $\mathrm{M} \mathrm{NaOH}$, at $4^{\circ} \mathrm{C}$ for $4 \mathrm{~h}$ ) overcame this problem and provided good results for the immunostaining of heterocysts. Immunoreactivity was observed in $75 \%$ of heterocysts (including proheterocysts), but staining was not detected in vegetative cells (Appendix 1: Fig. A7E, Table 1). Damage of vegetative cells by SDS treatment was a concern, but they remained intact since there were no morphological changes, and no leakage of phycobiliproteins occurred. The orange to red-fluorescence emitted mainly from phycobiliproteins in vegetative cells did not alter after SDS treatment (Fig. A7F vs. G). Non-specific reactions with endogenous peroxidases were negligible in all strains because oxidation of DAB did not occur unless cells were incubated with an HRP-conjugated secondary antibody (for Trichodesmum cf. Ohki 2008).

We did not apply this protocol to the oceanic unicellular diazotrophic strains. However, the nitrogenase of the unicellular diazotrophic strains used in the present study is phylogenetically close to that of oceanic strains Crocosphaera watsonii WH8501 and Synechocystis sp. WH001 (Ohki et al. 2008). Furthermore, our protocol detected nitrogenase that is phylogenetically different from that of oceanic strains (Trichodesmium and A. cylindrica), suggesting that this protocol will also be applicable to the detection of nitrogenase in oceanic strains.

\section{Model experiments}

The final goal of this study was to detect nitrogenase in unidentified oceanic diazotrophic unicellular cyanobacteria. Natural seawaters contain a mixture of diazotrophic and non-diazotrophic cells of various species. In order to be confident that our immunocytochemical protocol would discriminate between diazotrophic and non-diazotrophic cells in ocean waters, we mixed a known number of cells from different strains (including non-diazotrophic cells) and quantified the number of immunoreactive cells. The results are shown in Fig. 5 and Fig. A8 of Appendix 1 and also summarized in Table 2. The abundance of immunostained cells in the mixture of cells corresponded well with the expected values. We are currently attempting to apply our protocol to oceanic samples that contain diazotrophic and non-diazotrophic cells.

\section{CONCLUSION}

We have overcome two critical problems of the immunocytochemical detection of cytoplasmic proteins in single cells of cyanobacteria, that is, antibody penetration through thick cell walls and the autofluorescent masking of immunoreactivity when using fluorescent secondary antibodies. The cells of unicellular and filamentous non-heterocystous cyanobacteria were successfully permeabilized for antibody penetration by DMSO treatment without cell collapse. Furthermore, the immunoreactive signal was amplified by an enzyme-conjugated secondary antibody and visualized with a chro-

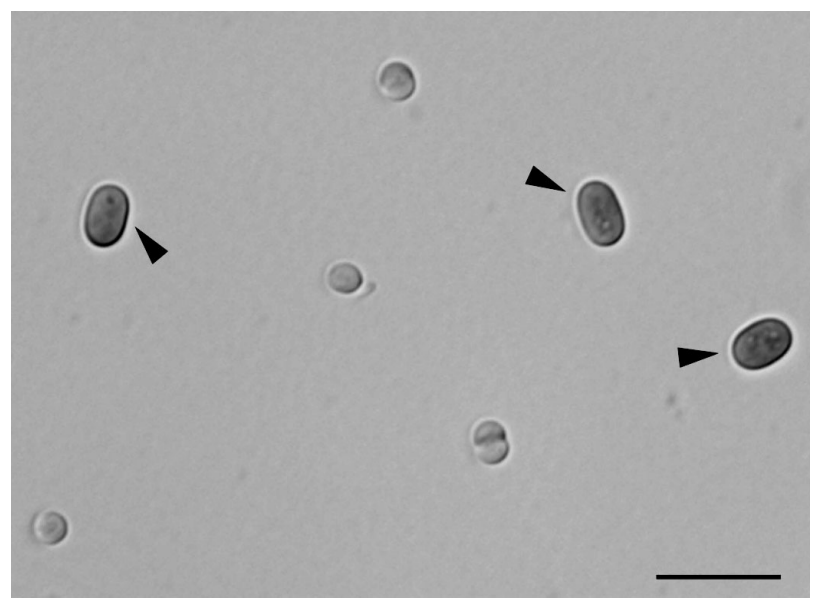

Fig. 5. Immunocytochemical detection of nitrogenase (Fe-protein) in mixed cell suspensions of a diazotrophic strain Gloeothece sp. 68DGA (arrowheads) and a non-diazotrophic strain Synechocystis sp. PCC6714. Scale bar $=10 \mu \mathrm{m}$. Color image is available online as AME Supplementary Material (Appendix 1: Fig. A8) at: www.int-res.com/ articles/suppl/ a051p237_app.pdf 
mogenic probe to avoid the masking effect of bright autofluorescence. Our protocol has several advantages: (1) it can be applied to various types of cyanobacteria, including unicellular and filamentous non-heterocystous cyanobacteria, without interference from autofluorescence; (2) the fixed cells can be preserved for at least 6 mo without a decrease in protein antigenicity; (3) the use of expensive epifluorescence microscopes is not necessary to detect immunoreactivity; (4) immunostained cells can be kept for at least $1 \mathrm{wk}$; and lastly (5) enzymeconjugated antibodies are relatively inexpensive. We chose nitrogenase as a target protein not only because of its ecological importance but also because of its usefulness as a tool for the evaluation of immunocytochemical methods, since its expression is easily regulated by nitrogen sources. This protocol will be applicable to the detection of other intracellular proteins, especially cytoplasmic proteins, in cyanobacteria.

Acknowledgements. This work was supported in part by a Sasakawa Scientific Research Grant from The Japan Science Society to Y.T, a Grant-in-Aid for Creative Scientific Research (No.17GS0314) from the Japan Society for the Promotion of Science to A.M., and a Grant-in-Aid for Scientific Research (C, No. 20580208) from the Japan Society for the Promotion of Science to K.O. We thank Drs. M. Kamiya and S. Yoshikawa of the Department of Marine Bioscience, Fukui Prefectural University, for their intensive discussion. We are also grateful to Ms. H. Uchida of Kobe University Research Center for Inland Seas for her technical assistance in the use of the microscope fluorometer.

\section{LITERATURE CITED}

Berman-Frank I, Lundgren P, Chen YB, Küpper H, Kolber Z, Bergman B, Falkowski P (2001) Segregation of nitrogen fixation and oxygenic photosynthesis in the marine cyanobacterium Trichodesmium. Science 294:1534-1537

Biegala IC, Raimbault P (2008) High abundance of diazotrophic picocyanobacteria $(<3 \mu \mathrm{m})$ in a Southwest Pacific coral lagoon. Aquat Microb Ecol 51:45-53

Campbell L, Carpenter EJ, Iacono VJ (1983) Identification and enumeration of marine chroococcoid cyanobacteria by immunofluorescence. Appl Environ Microbiol 46:553-559

Capone DG, Burns JA, Montoya JP, Ajit S and others (2005) Nitrogen fixation by Trichodesmium spp.: an important source of new nitrogen to the tropical and subtropical North Atlantic Ocean. Global Biogeochem Cycles 19:GB2024, doi:10.1029/2004GB002331

Carr NG, Mann NH (1994) The oceanic cyanobacterial picoplankton. In: Bryant DA (ed) The molecular biology of Cyanobacteria. Kluwer Academic Publishers, Dordrecht, p $27-48$

Church MJ, Short CM, Jenkins BD, Karl DM, Zehr JP (2005) Temporal patterns of nitrogenase gene (nifH) expression in the oligotrophic North Pacific Ocean. Appl Environ Microbiol 71:5362-5370

El-Shehawy R, Lugomela C, Ernst A, Bergman B (2003) Diurnal expression of hetR and diazocyte development in the filamentous non-heterocystous cyanobacterium Trichodesmium erythraeum. Microbiology 149:1139-1146

Falcón LI, Lindvall S, Bauer K, Bergman B, Carpenter EJ (2004a) Ultrastructure of unicellular $\mathrm{N}_{2}$ fixing cyanobacteria from the tropical North Atlantic and subtropical North Pacific Oceans. J Phycol 40:1074-1078

Falcón LI, Carpenter EJ, Cipriano F, Bergman B, Capone DG (2004b) $\mathrm{N}_{2}$ fixation by unicellular bacterioplankton from the Atlantic and Pacific Oceans: phylogeny and in situ rates. Appl Environ Microbiol 70:765-779

Fredriksson C, Bergman B (1997) Ultrastructural characterization of cells specialized for nitrogen fixation in a nonheterocystous cyanobacterium, Trichodesmium spp. Protoplasma 197:76-85

Galloway JN, Dentener FJ, Capone DG, Boyer EW and others (2004) Nitrogen cycles; past, present and future. Biogeochemistry 70:153-226

Gantt E (1994) Supramolecular membrane organization. In: Bryant DA (ed) The molecular biology of Cyanobacteria. Kluwer Academic Publishers, Dordrecht, p 119-138

Küpper H, Ferimazova N, Šetlík I, Berman-Frank I (2004) Traffic lights in Trichodesmium. Regulation of photosynthesis for nitrogen fixation studied by chlorophyll fluorescence kinetic microscopy. Plant Physiol 135: $2120-2133$

Lin S, Carpenter EJ (1996) An empirical protocol for wholecell immunofluorescence of marine phytoplankton. J Phycol 32:1083-1094

> Lin S, Heneze S, Lundgren P, Bergman B, Carpenter EJ (1998) Whole-cell immunolocalization of nitrogenase in marine diazotrophic cyanobacteria Trichodesmium spp. Appl Environ Microbiol 64:3052-3058

Mackinney G (1941) Absorption of light by chlorophyll solution. J Biol Chem 140:315-322

Madan AP, Nierzwicki-Bauer SA (1993) In situ detection of transcripts for ribulose-1,5-bisphosphate carboxylase in cyanobacterial heterocysts. J Bacteriol 175:7301-7306

> Mahaffey C, Michaels AF, Capone DG (2005) The conundrum of marine $\mathrm{N}_{2}$ fixation. Am J Sci 305:546-595

> Mazard SL, Fuller NJ, Orcutt KM, Bridle O, Scanlan DJ (2004) PCR analysis of the distribution of unicellular cyanobacterial diazotrophs in the Arabian Sea. Appl Environ Microbiol 70:7355-7364

Milligan AJ, Berman-Frank I, Gerchman Y, Dismukes GC, Falkowski PG (2007) Light-dependent oxygen consumption in nitrogen-fixing cyanobacteria plays a key role in nitrogenase protection. J Phycol 43:845-852

Mitsui A, Kumazawa S, Takahashi A, Ikemoto H, Cao S, Arai $\mathrm{T}$ (1986) Strategy by which nitrogen-fixing unicellular cyanobacteria grow photoautotrophically. Nature 413: 514-530

> Morel FMM, Rueter JG, Anderson DM, Guillard RRL (1979) Aquil: a chemically defined phytoplankton culture medium for trace metal studies. J Phycol 15:135-141

> Mulholland MR, Capone DG (2000) The nitrogen physiology of the marine $\mathrm{N}_{2}$-fixing cyanobacteria Trichodesmium spp. Trends Plant Sci 5:148-153

Neveux J, Lantoine F, Vaulot D, Marie D, Blanchot J (1999) Phycoerythrins in the southern tropical and equatorial Pacific Ocean: evidence for new cyanobacterial types. J Geophys Res 104:3311-3321

Ohki K (2008) Intercellular localization of nitrogenase in a non-heterocystous cyanobacterium (Cyanophyte), Trichodesmium sp. NIBB1067. J Oceanogr 64:211-216

Ohki K, Fujita Y (1988) Aerobic nitrogenase activity measured as acetylene reduction in the marine non-heterocystous cyanobacterium Trichodesmium spp. grown under 
artificial conditions. Mar Biol 98:111-114

Ohki K, Rueter JG, Fujita Y (1986) Culture of the pelagic cyanophytes Trichodesmium erythraeum and T. thiebautii in synthetic medium. Mar Biol 91:9-13

Ohki K, Zehr JP, Fujita Y (1992a) Regulation of nitrogenase activity in relation to the light-dark regime in the filamentous non-heterocystous cyanobacterium Trichodesmium sp. NIBB1067. J Gen Microbiol 138:2679-2685

Ohki K, Zehr JP, Fujita Y (1992b) Trichodesmium: establishment of culture and characteristics of $\mathrm{N}_{2}$-fixation. In: Carpenter EJ, Capone DG, Rueter JG (eds) Marine pelagic cyanobacteria: Trichodesmium and other diazotrophs. Kluwer Academic Publishers, Dordrecht, p 307-318

Ohki K, Kumazawa S, Ho KK (1999) Non heterocystous and unicellular diazotrophic cyanobacteria isolated from the seas around Singapore. International Conference on Asian Network on Microbial Research. TISTR \& Riken, p 787-796

Ohki K, Kamiya M, Honda D, Kumazawa S, Ho KK (2008) Morphological and phylogenetical studies on unicellular diazotrophic cyanobacteria (Cyanophytes) isolated from the coastal waters around Singapore. J Phycol 44:142-151

Paerl HW, Priscu JC, Brawner DL (1989) Immunochemical localization of nitrogenase in marine Trichodesmium aggregates: relationship to $\mathrm{N}_{2}$ fixation potential. Appl Environ Microbiol 55:2965-2975

Reddy KJ, Haskell JB, Sherman DM, Sherman LA (1993) Unicellular, aerobic nitrogen-fixing cyanobacteria of the genus Cyanothece. J Bacteriol 175:1284-1292

Rippka R, Deruelles J, Waterbury JB, Herdman M, Stanier RY (1979) Generic assignments, strain histories and properties of pure cultures of cyanobacteria. J Gen Microbiol 111:1-61

Saino T, Hattori A (1978) Diel variation in nitrogen fixation by a marine blue-green alga, Trichodesmium thiebautii. Deep-Sea Res 25:1259-1263

Sambrook J, Russell DW (2001) Molecular cloning. Cold Spring Harbor Laboratory Press, New York

Scanlan DJ, Mann NH, Carr NG (1993) The response of

Editorial responsibility: Douglas Capone,

Los Angeles, California, USA the picoplanktonic marine cyanobacterium Synechococcus species WH7803 to phosphate starvation involves a protein homologous to the periplasmic phosphate-binding protein of Escherichia coli. Mol Microbiol 10: 181-191

Scanlan DJ, Silman NJ, Donald KM, Wilson WH, Carr NG, Joint I, Mann NH (1997) An immunological approach to detect phosphate stress in populations and single cells of photosynthetic picoplankton. Appl Environ Microbiol 63:2411-2420

> Schönhuber W, Zarda B, Eix S, Rippka R, Herdman M, Ludwig W, Amann R (1999) In situ identification of cyanobacteria with horseradish peroxidase-labeled, rRNA-targeted ologonucleotide probes. Appl Environ Microbiol 65: 1259-1267

Sherman LA, Meunier P, Colón-López MS (1998) Diurnal rhythms in metabolism: a day in the life of a unicellular, diazotrophic cyanobacterium. Photosynth Res 58:25-42

Taniuchi Y, Ohki K (2007) Relation between nitrogenase synthesis and activity in a marine unicellular diazotrophic strain, Gloeothece sp. 68DGA (Cyanophyte), grown under different light/dark regimens. Phycol Res 55:249-256

> Wasmund N, Voss M, Lochte K (2001) Evidence of nitrogen fixation by non-heterocystous cyanobacteria in the Baltic Sea and re-calculation of a budget of nitrogen fixation. Mar Ecol Prog Ser 214:1-14

Waterbury JB, Watson SW, Valois FW (1988) Temporal separation of photosynthesis and dinitrogen fixation in the marine unicellular cyanobacterium: Erythrosphaera marina. EOS 69:1089

Zehr JP, Ward BB (2002) Nitrogen cycling in the ocean: new perspectives on processes and paradigms. Appl Environ Microbiol 68:1015-1024

Zehr JP, Carpenter EJ, Villareal TA (2000) New perspectives on nitrogen-fixing microorganisms in tropical and subtropical oceans. Trends Microbiol 8:68-73

Zehr JP, Waterbury JB, Turner PJ, Montoya P and others (2001) Unicellular cyanobacteria fix $N_{2}$ in the subtropical North Pacific Ocean. Nature 412:635-638

Submitted: September 14, 2007; Accepted: February 13, 2008 Proofs received from author(s): June 11, 2008 